\title{
Search and Selection of Probiotics That Improve Mucositis Symptoms in Oncologic Patients. A Systematic Review
}

\author{
José Antonio Picó-Monllor ${ }^{1,2, *}$ and José Manuel Mingot-Ascencao ${ }^{2}$ \\ 1 Universidad Miguel Hernández, 03202 Elche, Spain \\ 2 Korott, s.l., 03801 Alcoy, Spain; jmingot@korott.com \\ * Correspondence: japico@umh.es; Tel.: +34-966526550
}

Received: 25 August 2019; Accepted: 29 September 2019; Published: 1 October 2019

check for updates

\begin{abstract}
Mucositis is a common and severe adverse effect of radiotherapy and/or chemotherapy treatments applied to oncologic patients. The development of effective therapies and adjuvant treatments to increase their efficacy and reduce adverse effect is a priority in cancer therapy. Probiotics are non-pathogenic live microorganisms that when ingested in adequate amounts can colonize the intestinal tract promoting the restoration of a healthy gut microbiota and contributing to all its functions including the maintenance of the integrity of the mucosa and the modulation of the immune system. In order to check the possible efficacy and safety of these microorganisms to prevent or ameliorate mucositis' symptoms, we have systematically searched the bibliographic databases MEDLINE (via Pubmed), EMBASE, The Cochrane library, Scopus, Web of science, and Latin American and Caribbean Literature in Health of Sciences (LILACS) using the descriptors "Mucositis", "Probiotics", "Neoplasms", "Humans", and "Clinical Trials". After applying our inclusion and exclusion criteria, 15 studies were accepted for review and critical analysis. Our analysis suggests that a combination of Bifidobacterium longum, Lactobacillus acidophilus, Bifidobacterium breve, Bifidobacterium infantis, and Saccharomyces boulardii could be a good combination of probiotics to reduce incident rates of mucositis or ameliorate its symptoms in chemo or radiotherapy treated patients.
\end{abstract}

Keywords: mucositis; probiotics; neoplasms

\section{Introduction}

Mucositis is a common and severe adverse effect of chemotherapy or radiotherapy treatments applied to oncologic patients. It can affect any part of the mucosa layer of the gastrointestinal tract from the mouth to the anus. It happens in $20 \%-40 \%$ of the patients undergoing conventional chemotherapy, $80 \%$ of patients receiving high chemotherapy doses, $60 \%-80 \%$ of patients receiving hematopoietic cell transplants, and in almost all patients with squamous cell carcinoma of the head and neck undergoing radiotherapy [1-4].

\subsection{Pathogenesis}

Although mucositis is a process that occurs continuously over time, it is frequently divided into five stages, namely, initiation, primary damage response, signal amplification, ulceration, and healing [5]. The initiation or first damage induced by chemo or radiotherapy involves DNA damage and the generation of reactive oxygen species in cells of both, the basal epithelium and the submucosa layer. These events lead to a primary damage response in all the mucosa layers, by the activation of several transcription factors, such as nuclear factor kappa-light-chain-enhancer of activated B cells (NF-kB) [6], that regulate the expression of many genes involved in inflammation and mucosa damage 
such as interleukin 1-beta (IL-1 $\beta$ ), tumor necrosis factor alfa (TNF- $\alpha$ ), interleukin 6 (IL-6), and the metalloproteases (MMP) MMP1 and MMP3 whose activity degrades subepithelial matrix and the epithelial basement membrane [7]. Positive-feedback loops between some of these molecules, as the activation of NF- $\mathrm{kB}$ by TNF- $\alpha$ or MMP1 and MMP3 by TNF- $\alpha$ and IL-1 $\beta$, further amplify the activated signalling pathways finally leading to the mucosa damage or ulcer. Loss of mucosa integrity causes severe pain and increases the risk of bacteria translocation and, therefore, the risk of bacteremia and sepsis. Finally, once the therapy finishes, in most of the cases the ulcer heals.

\subsection{Assessment Scales Mucositis}

Clinically, mucosa injury can be assessed by different criteria. One of the most widely used for mucositis evaluation in clinical trials has been stablished by the World Health Organization (WHO) [8]. By these criteria, mucositis is classified, as severity increases, from grade 0 to grade 4 . Mucositis is classified as grade 0 when the patient shows no signs or symptoms; grade 1 when the patient has painless ulcers, edema, or mild pain; grade 2 when there is painful erythema, edema, or ulcers but the patient is able to eat; grade 3 when the patient has the same symptoms as in grade 2 but is unable to eat; and, finally, grade 4 when parenteral or enteral feeding is needed (Table 1). Severe mucositis usually requires a decrease in the dose of treatment or even its temporary interruption which negatively affects the prognosis of patients $[9,10]$. Besides the negative effects of mucositis in cancer patients, this pathology also has a significant economic impact due to the costs associated with the treatment of symptoms, nutritional requirements, treatment of secondary infections, and hospitalization expenses [9-11].

Table 1. Mucositis degrees according to $\mathrm{WHO}[8]$.

\begin{tabular}{ccccc}
\hline Grade 0 & Grade 1 & Grade 2 & Grade 3 & Grade 4 \\
\hline $\begin{array}{c}\text { No signs or } \\
\text { symptoms }\end{array}$ & $\begin{array}{c}\text { Painless ulcers, } \\
\text { edema or mild pain }\end{array}$ & $\begin{array}{c}\text { Painful erythema, edema or } \\
\text { ulcers but the patient can eat }\end{array}$ & $\begin{array}{c}\text { Idem grade 2 but } \\
\text { unable to eat }\end{array}$ & $\begin{array}{c}\text { Parenteral or enteral } \\
\text { feeding is needed }\end{array}$ \\
\hline
\end{tabular}

\subsection{Drugs}

Therapy options for mucositis treatment are continuously been developed and many kinds of drugs, targeting different molecular pathways involved in the pathology or alleviating some of its symptoms, are currently been used [12]. This battery of drugs includes reactive oxygen species, protective molecules such as amifostine and n-acetyl cysteine, a keratinocyte growth factor inhibitor, palifermin, nonsteroidal anti-inflammatories such as benzydamine $\mathrm{HCl}, \mathrm{TNF}-\alpha$ inhibitors such as pentoxifylline, and mono or polyclonal antibodies against TNF- $\alpha$ or Il- 6 . However, these drugs are not very efficient [1] and the development of effective therapies or adjuvant treatments to increase their efficacy and reduce adverse effect is a priority in the cancer therapy field.

When mucositis affects the intestinal mucosa, it is usually accompanied by nausea, vomiting, diarrhea, abdominal pain, bleeding, dehydration, electrolyte imbalance, immunosuppression, weakening of the intestinal barrier, and dysbiosis [1]. The combination of a damaged intestinal mucosa, dysbiosis, and immunosuppression favors the translocation and subsequent bacterial spread that can cause systemic infections that constitute a severe complication in cancer patients [13]. In order to prevent or treat these infections, patients are treated with broad-spectrum antibiotics. These antibiotics further weaken the intestinal microbiota and induce a greater degradation of the mucosa, with the latter favoring the possible bacterial translocation.

\subsection{Microbiota}

The human intestinal microbiota plays a fundamental role in the maintenance of homeostasis and intestinal integrity. It is made up of billions of microorganisms present in our digestive tract with which we maintain a mutually beneficial relationship that has developed over millions of years. This set of microorganisms is starting to be considered as another organ of our body as it is involved in 
many functions such as the proper metabolism of several nutrients, the maintenance of the intestinal mucosa, the modulation of inflammatory and immune responses, and the reduction of oxidative stress. In addition, it constitutes an essential barrier against pathogenic organisms being crucial to avoid colonization of the intestinal mucosa by exogenous microbes and to prevent their translocation and subsequent invasion of other organs and tissues [14]. Patients undergoing chemotherapy or radiotherapy have altered the intestinal microbiota and these alterations could be involved in the development of mucositis and the aggravation of some of its symptoms as diarrhea and bacteremia. Thus, keeping or restoring a healthy gut microbiota could be a key factor in decreasing the incidence rates of mucositis or ameliorate its symptoms.

\subsection{Probiotics}

Probiotics are non-pathogenic live microorganisms which when administered in adequate amounts confer health benefits on the host [15]. The number of studies in which they have successfully been used to attenuate or prevent symptoms related to several pathologies is constantly growing and consumers are increasingly aware of their existence and their benefits. This has made the probiotics sector one of the fastest growing sectors among functional foods with a market valued at 32.06 US billion dollars in 2013 and expected to reach 46.55 US billion dollars by 2020. Since more and more people and healthcare staff are concerned about probiotics benefits, their consumption is constantly growing [16].

The main objective of this work is to systematically review available data related with the efficacy and safety of the use of probiotics to treat or prevent mucositis in oncologic patients and identify the best putative candidates for this purpose.

\section{Materials and Methods}

\subsection{Source of Data Collection}

The aim of this descriptive study is to critically and systematically review articles published in the following data bases: MEDLINE (via PubMed), EMBASE, SCOPUS, Cochrane Library Plus, Institute for Scientific Information (ISI)-Web of Science, and Latin American and Caribbean Literature in Health Sciences (LILACS).

\subsection{Information Processing}

Thesaurus, a tool developed by the U.S. National Library of Medicine, was used to determine the data search. The entry terms "Mucositis", "Probiotics", and "Neoplasms", in text format, were used as descriptors in the title and abstract. The final search equation for searching MEDLINE data base, via PubMed, was developed using Boolean connectors and the filters "Humans" and "Clinical Trial" with the following results:

("Neoplasms"[Mesh] OR “Neoplasms"[Title/Abstract] OR “Neoplasia"[Title/Abstract] OR “Neoplasias"[Title/Abstract] OR “Neoplasm"[Title/Abstract] OR “Tumors"[Title/Abstract] OR "Tumor"[Title/Abstract] OR "Malignant Neoplasms"[Title/Abstract] OR "Malignant Neoplasm"[Title/Abstract])) AND ("Probiotics"[Mesh] OR "Probiotics"[Title/Abstract] OR "Probiotic"[Title/Abstract])) AND ("Mucositis"[Mesh] OR "Mucositis"[Title/Abstract] OR "Mucositides" [Title/Abstract]). The same scheme was arranged after considering the different features of the remaining database.

The search was conducted from the first available date, until June 2019 (date of the last update). In addition, as a secondary search and in order to reduce the number of not retrieved studies, the bibliography of the articles selected in the first search were analysed, looking for studies not detected in the primary search. 


\subsection{Final Selection of Articles}

The final selection of the articles was done based on the following inclusion criteria: The documents had to be clinical studies published in peer-reviewed journals, written in English, Spanish, or Portuguese and from which the full text could be retrieved. Also, there was an exclusion of all studies either not performed on humans or which did not focus the intervention (probiotics) on the effect over mucositis.

Relevant articles were independently selected by the two authors (J-P and J-M) of this review. In order to validate the choice of the articles, it was established that the value of the agreement between these two authors (Kappa index) had to be greater than 0.80 (a score that guarantees a very good strength of the agreement). Whenever this condition was met, possible disagreements between the authors would be resolved by consulting an expert in the field and a subsequent consensus between the authors [17].

The quality of the selected articles was evaluated according to the guidelines of the Consolidated Standards of Reporting Trials (CONSORT) [18] that contains 25 essential issues that must be described and evaluated in the publication of this type of studies. In each selected article, the items were given a " 1 " or " 0 " depending on whether they contained the information mentioned in CONSORT. If the evaluation of an item was not necessary, that point was not counted in the total score (Not Applicable = NA). When an item was made up of two points, these were independently evaluated and subsequently averaged in such a way that in no case the score of the item could be greater than one.

\subsection{Data Extraction}

The information extracted from the articles reviewed in this essay was controlled by double-entry tables which permitted the detection of errors and, at the same time, their correction by checking the original one again.

To establish the actuality of the articles, the Burton-Kebler half-period (the median age) and the Price index (percentage of articles with an age of less than five years) were calculated. The articles were grouped according to the variables under study, in order to systematize and facilitate the understanding of the results, coding the following data: First author and year of publication, study design, country where the study was conducted, study population, pathology, period in which the work was carried out, what type of intervention took place, and results obtained.

\section{Results}

When applying the described search criteria, a total of 192 references were retrieved: 88 (45.83\%) in EMBASE, 42 (21.87\%) in Scopus, 38 (19.79\%), 18 (9.38\%), in MEDLINE, 6 (3.12\%) in Web of science, and 0 in LILACS. From all the identified articles, $48(25 \%)$ were rejected because they were duplicated in more than one bibliographic database. After applying the inclusion and exclusion criteria (Figure 1), of the remaining $144(75 \%), 15$ studies $(7.81 \%)$ were accepted for review and critical analysis (Table 2$)$. 


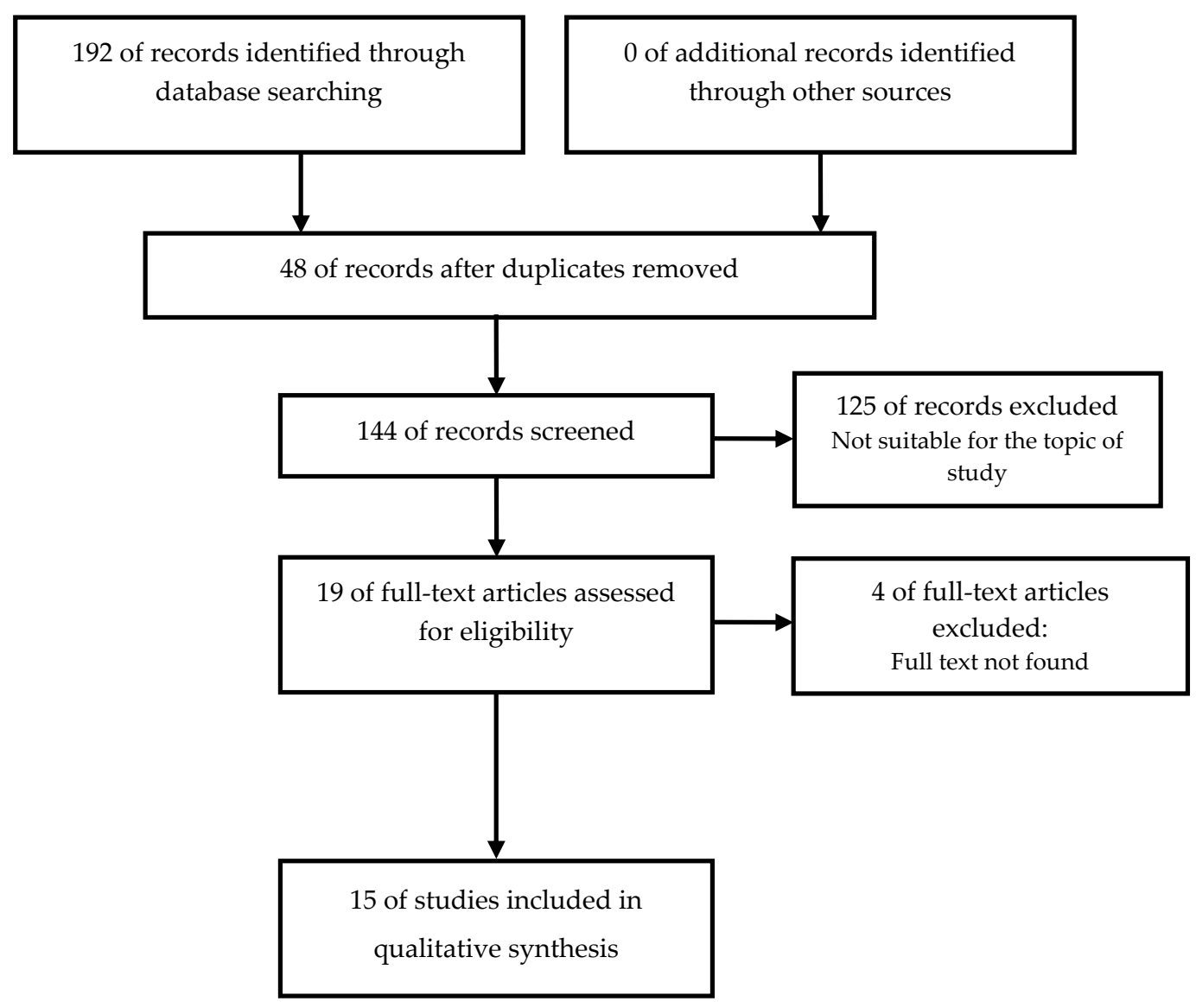

Figure 1. Identification and selection of studies according to Preferred Reporting Items for Systematic Reviews and Meta-Analyses (PRISMA statement [19].

The agreement on the pertinence of the selected studies was 100\%. The obsolescence of the chosen articles, according to the Burton-Kebler index, was 8.5 years, with a Price index of $27.7 \%$.

The quality assessment of the articles selected for this review by CONSORT [18] (Table 3) obtained a score between 9.5 and 24.5 over a maximum score of 25 items with a median equal to 17 . The calculation of the Kappa coefficient gave a measure of agreement in the selection of articles by the two authors of $98 \%$. 
Table 2. Summary of reviewed studies on the relationship probiotics and mucositis in cancer patients.

\begin{tabular}{|c|c|c|c|c|c|c|c|}
\hline Author, Year & Design & Country & Patients & Pathology & Monitoring & Intervention & Results \\
\hline $\begin{array}{c}\text { Jiang } 2008 \\
\text { [20] }\end{array}$ & $\begin{array}{l}\text { Randomized, } \\
\text { double-blind, } \\
\text { placebo-controlled } \\
\text { trial monocentric }\end{array}$ & China & $\begin{array}{c}99 \mathrm{M} / \mathrm{F}=58 / 35 \\
\text { Median age }=51 \\
\text { years }\end{array}$ & $\begin{array}{l}\text { Advanced } \\
\text { NC and } \\
\text { undergoing } \\
\text { CCRT }\end{array}$ & seven weeks & $\begin{array}{c}\text { CCRT and B.longum, L.lactis, } \\
\text { E.faecium. (six capsules/day) OM } \\
\text { incidence, the short-term curative } \\
\text { effect, the immune index, and fecal } \\
\text { flora changes. }\end{array}$ & $\begin{array}{l}\text { Probiotic combination reduced } \\
\text { the incidence of grade } 3 \mathrm{OM} \text { and } \\
\text { had significantly enhanced the } \\
\text { immunity of patients and was } \\
\text { beneficial for restoring microbial } \\
\text { diversity after the end of CCRT. }\end{array}$ \\
\hline $\begin{array}{c}\text { Gao } 2015 \\
{[21]}\end{array}$ & $\begin{array}{l}\text { Randomized } \\
\text { prospective } \\
\text { placebo-controlled } \\
\text { trial. }\end{array}$ & China & $\begin{array}{c}22 \mathrm{M} / \mathrm{F}=12 / 10 \\
\text { Median age }=70 \\
\text { years }\end{array}$ & CRC & $\begin{array}{l}\text { five days } \\
\text { perioperative } \\
\text { surgery }\end{array}$ & $\begin{array}{c}\text { B.longum L.acidophyllus, Efaecalis } \\
\quad(1: 1: 1) .6 \times 10^{7} \mathrm{CFU} / \text { day. } \\
\text { Oral probiotics were able to alter } \\
\text { the microbial composition and } \\
\text { improve gut microbiota in patients } \\
\text { with CRC. }\end{array}$ & $\begin{array}{l}\text { Probiotic supplements can } \\
\text { effectively alter the composition, } \\
\text { richness, and diversity of the } \\
\text { gut microbiota }\end{array}$ \\
\hline $\begin{array}{c}\text { Liu } 2010 \\
\text { [22] }\end{array}$ & $\begin{array}{l}\text { Randomized, } \\
\text { double-blind, } \\
\text { placebo-controlled, } \\
\text { prospective trial }\end{array}$ & China & $\begin{array}{c}100 \mathrm{M} / \mathrm{F}=59 / 41 \\
\text { Median age }=65 \\
\text { years }\end{array}$ & CRC & $\begin{array}{l}16 \text { days (six days } \\
\text { pre-and } 10 \text { days } \\
\text { post-operative) }\end{array}$ & $\begin{array}{l}\text { L.acidophillus, L.plantarum, B.longum } \\
\left(1 \times 10^{14} \mathrm{CFU} / \text { day). Preoperative }\right. \\
\text { administration could prevent } \\
\text { post-operative alterations in } \\
\text { intestinal permeability, integrity } \\
\text { and microbiota. }\end{array}$ & $\begin{array}{l}\text { Probiotics can improve the } \\
\text { integrity of the gut mucosal } \\
\text { barrier and balance of the gut } \\
\text { microbiota, and they play a role } \\
\text { in decreasing the infectious rate. }\end{array}$ \\
\hline $\begin{array}{c}\text { Gianotti } 2010 \\
\text { [23] }\end{array}$ & $\begin{array}{l}\text { Prospective, } \\
\text { randomized, } \\
\text { double-blind, } \\
\text { clinical trial }\end{array}$ & Italia & $\begin{array}{c}31 \mathrm{M} / \mathrm{F}=22 / 11 \\
\text { Median age }=64 \\
\text { years }\end{array}$ & CRC & $\begin{array}{l}\text { six days (three } \\
\text { pre- and three } \\
\text { post-operative) }\end{array}$ & $\begin{array}{l}\text { B.longum and L.johnsonii }\left(2 \times 10^{7}\right. \\
\text { and } 2 \times 10^{9} \mathrm{CFU} / \text { day). Assess } \\
\text { adhesion to the colonic mucosa, } \\
\text { reduce concentration of pathogens } \\
\text { in stools, and modulate local } \\
\text { immune function. }\end{array}$ & $\begin{array}{l}\text { L.johnsonii but not B.longum, } \\
\text { adhere to the colonic mucosa, } \\
\text { affect intestinal microbiota by } \\
\text { reducing the concentration of } \\
\text { pathogens, and modulate } \\
\text { local immunity. }\end{array}$ \\
\hline $\begin{array}{c}\text { Worthley } 2009 \\
\text { [24] }\end{array}$ & $\begin{array}{l}\text { Randomized, } \\
\text { double-blind, } \\
\text { placebo-controlled } \\
\text { crossover trial }\end{array}$ & Australian & $\begin{array}{c}20 \\
\mathrm{M} / \mathrm{F}=13 / 7 \text { Median } \\
\text { age }=65.5 \text { years }\end{array}$ & Healthy & 16 weeks & $\begin{array}{l}\text { (B.animalis sub.lactis } 5 \times 10^{9} \\
\text { CFU/day }+25 \text { g/day HAMS), } \\
\text { Synbiotic. Characterized the } \\
\text { luminal and biological } \\
\text { consequences of these supplements } \\
\text { and placed them in the context of } \\
\text { colorectal carcinogenesis. }\end{array}$ & $\begin{array}{c}\text { Synbiotic generated } \\
\text { a significantly different fecal } \\
\text { bacteria profile when compared } \\
\text { with either HAMS or B.animalis } \\
\text { sub.lactis supplementation alone. }\end{array}$ \\
\hline
\end{tabular}


Table 2. Cont

\begin{tabular}{|c|c|c|c|c|c|c|c|}
\hline Author, Year & Design & Country & Patients & Pathology & Monitoring & Intervention & Results \\
\hline $\begin{array}{c}\text { Friederich } 2011 \\
\text { [25] }\end{array}$ & $\begin{array}{l}\text { Randomized pilot } \\
\text { study }\end{array}$ & Netherlands & $\begin{array}{c}31 \\
\mathrm{M} / \mathrm{F}=20 / 11 \\
\text { Median age }=37 \\
\text { years }\end{array}$ & $\begin{array}{l}\text { FAP and } \\
\text { IPAA }\end{array}$ & six weeks & $\begin{array}{l}\text { Sulindac (300 mg/day), VSL\#3 } \\
\left(9 \times 10^{11} \mathrm{CFU} / \text { day }\right)+\text { Inulin } \\
(12 \mathrm{~g} / \text { day). Endpoints: Risk } \\
\text { parameters cell proliferation and } \\
\text { GST detoxification capacity in the } \\
\text { pouch mucosa. SCFA contents, } \mathrm{pH} \text {, } \\
\text { and cytotoxicity of fecal water. }\end{array}$ & $\begin{array}{l}\text { Study revealed non-significant } \\
\text { decreased cell proliferation and } \\
\text { increased detoxification capacity } \\
\text { after treatment with sulindac or } \\
\text { VSL\#3/inulin (prebiotic). }\end{array}$ \\
\hline $\begin{array}{c}\text { Lacouture } 2016 \\
{[26]}\end{array}$ & $\begin{array}{c}\text { Multicenter, } \\
\text { double cohort } \\
\text { placebo-controlled } \\
\text { randomized phase } \\
\text { II trial }\end{array}$ & $\begin{array}{l}\text { USA and } \\
\text { Republic. of } \\
\text { Korea }\end{array}$ & $\begin{array}{c}173 \mathrm{M} / \mathrm{F}=98 / 75 \\
\text { Median age }=66 \\
\text { years }\end{array}$ & $\begin{array}{l}\text { Advanced } \\
\text { NSCLC }\end{array}$ & $\begin{array}{l}\text { four to eight } \\
\text { weeks according } \\
\text { to treatment }\end{array}$ & $\begin{array}{c}\text { Dacomitinib all cohorts Cohort I: } \\
\text { Doxycycline + placebo. Cohort II: } \\
\text { AD+ VSL\#3. Cohorts I and II } \\
\text { assessment incidence of all grade } \\
\text { and grade } \geq 2 \text { SDAEI and QoL. } \\
\text { Cohort II assessment incidence of } \\
\text { all grade and grade } \geq 2 \text { diarrhea } \\
\text { and mucositis }\end{array}$ & $\begin{array}{l}\text { Doxycycline was effective as } \\
\text { a prophylactic treatment for } \\
\text { dacomitinib-induced grade } \geq 2 \\
\text { SDAEI. Both doxycycline and AD } \\
\text { reduced the negative impact in } \\
\text { patient-reported dermatologic } \\
\text { AEs. The probiotic was not } \\
\text { effective for preventing diarrhea } \\
\text { or mucositis }\end{array}$ \\
\hline $\begin{array}{c}\text { Hegazy } 2010 \\
\text { [27] }\end{array}$ & $\begin{array}{l}\text { Multicenter, } \\
\text { placebo-controlled } \\
\text { randomized }\end{array}$ & Egypt & $\begin{array}{c}40 \mathrm{M} / \mathrm{F}=29 / 11 \\
\text { Median age }=47 \\
\text { years }\end{array}$ & UC & eight weeks & $\begin{array}{c}\text { L.delbruekii and L.fermentum } \\
1 \times 10^{10} \mathrm{CFU} / \text { day. Effect in patients } \\
\text { with ulcerative colitis (UC), and } \\
\text { their effect on inflammatory } \\
\text { mediators and NF-KB activation }\end{array}$ & $\begin{array}{l}\text { Oral supplementation with } \\
\text { probiotics could be helpful in } \\
\text { maintaining remission and } \\
\text { preventing relapse of UC }\end{array}$ \\
\hline $\begin{array}{c}\text { Groeger } 2013 \\
{[28]}\end{array}$ & $\begin{array}{l}\text { Randomized, } \\
\text { double-blind, } \\
\text { placebo-controlled }\end{array}$ & Ireland & $\begin{array}{c}118 \\
\mathrm{M} \text { and } \mathrm{F}=48 \\
\text { (UC and Psoriasis) } \\
\mathrm{F}=83(\mathrm{CFS} \text { and } \\
\text { healthy) }\end{array}$ & $\begin{array}{l}\text { UC. Psoriasis. } \\
\text { CFS. Healthy. }\end{array}$ & six - eight weeks & $\begin{array}{l}\text { B. infantis strain } 35,6241 \times 10^{10} \\
\text { CFU/day Assessed the impact on } \\
\text { inflammatory biomarker and } \\
\text { plasma cytokine levels in UC, CFS, } \\
\text { and psoriasis }\end{array}$ & $\begin{array}{c}\text { B.infantis strain } 35,624, \\
\text { was enough to reduce systemic } \\
\text { inflammatory biomarkers in both } \\
\text { gastrointestinal and } \\
\text { extra-intestinal } \\
\text { inflammatory disorders. }\end{array}$ \\
\hline $\begin{array}{c}\text { Sharma } 2012 \\
\text { [29] }\end{array}$ & $\begin{array}{l}\text { Randomized, } \\
\text { double-blind, } \\
\text { single center, } \\
\text { placebo controlled }\end{array}$ & India & $\begin{array}{c}200 \mathrm{M} / \mathrm{F}=188 / 12 \\
\text { Median age = } 51 \\
\text { years }\end{array}$ & $\begin{array}{c}\text { HNSCC } \\
\text { stage II-IVA }\end{array}$ & 25 months & $\begin{array}{l}\text { L.brevis strain CD2 } 2 \times 10^{9} \text { efficacy } \\
\text { in preventing oral mucositis in } \\
\text { patients receiving CRT for HNSCC. }\end{array}$ & $\begin{array}{l}\text { L.brevis strain CD2 proved to be } \\
\text { safe and efficacious in reducing } \\
\text { the incidence of severe oral } \\
\text { mucositis in patients with } \\
\text { HNSCC undergoing combination } \\
\text { radiation and chemotherapy }\end{array}$ \\
\hline
\end{tabular}


Table 2. Cont.

\begin{tabular}{|c|c|c|c|c|c|c|c|}
\hline Author, Year & Design & Country & Patients & Pathology & Monitoring & Intervention & Results \\
\hline $\begin{array}{c}\text { D Sanctis } 2019 \\
\text { [30] }\end{array}$ & $\begin{array}{l}\text { Multicentric, } \\
\text { phase III, open } \\
\text { label, randomized } \\
\text { controlled }\end{array}$ & Italy & $\begin{array}{c}68 \mathrm{M} / \mathrm{F}=53 / 15 \\
\text { Median age }=60 \\
\text { years }\end{array}$ & HNC & 39 months & $\begin{array}{l}\text { L.brevis strain } \mathrm{CD} 22 \times 10^{9} \text { primary } \\
\text { endpoint was the incidence of } \\
\text { grade } 3 \text { or } 4 \text { oropharyngeal } \\
\text { mucositis during } \\
\text { radiotherapy treatment }\end{array}$ & $\begin{array}{l}\text { L.brevis strain CD2 not able to } \\
\text { confirm the beneficial effects in } \\
\text { reducing the rate of grade } \\
\text { 3-4 RT-induced OM in patients } \\
\text { with HNC. }\end{array}$ \\
\hline $\begin{array}{c}\text { Consoli } 2015 \\
\text { [31] }\end{array}$ & $\begin{array}{l}\text { Randomized } \\
\text { controlled }\end{array}$ & Brazil & $\begin{array}{c}33 \mathrm{M} / \mathrm{F}=15 / 18 \\
\text { Median age = } 55 \\
\text { years }\end{array}$ & $\mathrm{RC}$ & $\begin{array}{l}\text { seven days } \\
\text { before surgery } \\
\text { and was } \\
\text { interrupted on } \\
\text { the operation } \\
\text { day. }\end{array}$ & $\begin{array}{l}\text { S.boulardii } 0.5 \times 10^{9} \mathrm{CFU} \text { to assess } \\
\text { the role of preoperative treatment } \\
\text { on mRNA levels for } \\
\text { immunomodulatory cytokines in } \\
\text { the colonic mucosa of patients. }\end{array}$ & $\begin{array}{l}\text { S.boulardii downregulates both } \\
\text { pro- and anti-inflammatory } \\
\text { cytokines in the intestinal colonic } \\
\text { mucosa with no statistical impact } \\
\text { on postoperative infection rates. }\end{array}$ \\
\hline $\begin{array}{l}\text { Wada } 2009 \\
\text { [32] }\end{array}$ & $\begin{array}{l}\text { Randomized, } \\
\text { placebo-controlled } \\
\text { single-blinded }\end{array}$ & Japan & $\begin{array}{c}40 \mathrm{M} / \mathrm{F}= \\
\text { 16/24Median age }= \\
6.5 \text { years }\end{array}$ & IC & one to five weeks & $\begin{array}{l}\text { B.breve strain Yakult } 10^{9} \mathrm{CFU} \text {, on its } \\
\text { ability to prevent infection, fecal } \\
\text { micro flora, and intestinal } \\
\text { environments in cancer patients } \\
\text { on chemotherapy. }\end{array}$ & $\begin{array}{l}\text { B.breve strain Yakult could be an } \\
\text { effective approach for achieving } \\
\text { clinical benefits in } \\
\text { immunocompromised hosts by } \\
\text { improving their intestinal } \\
\text { environments (mucositis, fever, } \\
\quad \text { diarrhea and bacteremia). }\end{array}$ \\
\hline $\begin{array}{c}\text { Mangell } 2012 \\
\text { [33] }\end{array}$ & $\begin{array}{c}\text { Randomized } \\
\text { double-blinded, } \\
\text { placebo-controlled }\end{array}$ & Sweden & $\begin{array}{c}64 \mathrm{M} / \mathrm{F}= \\
\text { 36/28Median age = } \\
72 \text { years }\end{array}$ & $\mathrm{RC}$ & six months & $\begin{array}{l}\text { L.plantarum strain } 299 \mathrm{v} 10^{11} \mathrm{CFU} \\
\text { on the intestinal load of potentially } \\
\text { pathogenic bacteria, bacterial } \\
\text { translocation, and cell proliferation } \\
\text { in elective colon surgery. }\end{array}$ & $\begin{array}{c}\text { L.plantarum strain } 299 \mathrm{v} \text { was } \\
\text { established in the intestine, } \\
\text { but no inhibitory effect on enteric } \\
\text { bacteria, bacterial translocation, } \\
\text { or postoperative complications } \\
\text { was found }\end{array}$ \\
\hline $\begin{array}{l}\text { Ouwehan. } \\
2008 \\
{[34]}\end{array}$ & $\begin{array}{c}\text { Randomized } \\
\text { double-blinded, } \\
\text { placebo-controlled }\end{array}$ & Finland & $\begin{array}{c}47 \mathrm{M} / \mathrm{F}= \\
\text { 12/35Median age }= \\
71 \text { years }\end{array}$ & $\begin{array}{l}\text { Healthy and } \\
\text { regular use } \\
\text { of NSAID }\end{array}$ & six weeks & $\begin{array}{l}\text { Synbiotic (lactitol }+2 \times 10^{9} \text { CFU } \\
\text { L.acidophyllus strain NCFM) on } \\
\text { improve bowel function and } \\
\text { immune function. }\end{array}$ & $\begin{array}{l}\text { Synbiotic twice daily was } \\
\text { associated with modest } \\
\text { improvement in stool frequency } \\
\text { without any side-effects and } \\
\text { improved microbiota } \\
\text { composition and mucosal. }\end{array}$ \\
\hline \multicolumn{8}{|c|}{$\begin{array}{l}\text { M/F: Number males and females. NC: Nasopharyngeal Carcinoma. CCRT: Concurrent Chemoradiotherapy. OM: Oral mucositis. CRC: Colorectal cancer. B: Bifidobacterium. L: Lactobacillus. } \\
\text { E: Enterobacteria. CFU: Colony-forming units. HMAS (prebiotic): High-Amylose Maize Starch. FAP: Familial adenomatous polyposis. IPAA: Ileal pouch anal anastomosis. Sulindac: } \\
\text { Non-steroidal anti-inflammatory drug. VSL\#3: Mix probiotic. SCFA: Short chain fatty acid. GST: Glutathione S-transferase. NSCLC: Non-small cell lung cancer. QoL: Quality of life. } \\
\text { SDAEI: Select dermatologic adverse events of interest. AD: Alclometasone dipropionate. Dacomitinib: Inhibitor of the human epidermal growth factor receptor (HER). AEs: Adverse } \\
\text { events. Doxycycline: Broad-spectrum antibiotic. UC: Ulcerative colitis. CFS: Chronic fatigue syndrome. HNSCC: Head and neck squamous cell carcinoma CRT: Chemo-radiotherapy. } \\
\text { HNC: Head and neck carcinoma. RT: Radiation therapy. NF KB: Nuclear factor kappa-light-chain-enhancer of activated B cells. mRNA: Messenger RNA. RC: Resection colon. IC: } \\
\text { Immunocompromised. NSAID: Non-steroidal anti-inflammatory. S: Saccharomyces. Lactitol (prebiotic): Disaccharide. }\end{array}$} \\
\hline
\end{tabular}


Table 3. Assessment of the methodological quality of the studies analyzed by means of the 25 items of the CONSORT 2010.

\begin{tabular}{ccccccccccccccccccccccccccccccc}
\hline & $\mathbf{1}$ & $\mathbf{2}$ & $\mathbf{3}$ & $\mathbf{4}$ & $\mathbf{5}$ & $\mathbf{6}$ & $\mathbf{7}$ & $\mathbf{8}$ & $\mathbf{9}$ & $\mathbf{1 0}$ & $\mathbf{1 1}$ & $\mathbf{1 2}$ & $\mathbf{1 3}$ & $\mathbf{1 4}$ & $\mathbf{1 5}$ & $\mathbf{1 6}$ & $\mathbf{1 7}$ & $\mathbf{1 8}$ & $\mathbf{1 9}$ & $\mathbf{2 0}$ & $\mathbf{2 1}$ & $\mathbf{2 2}$ & $\mathbf{2 3}$ & $\mathbf{2 4}$ & $\mathbf{2 5}$ & $\mathbf{T}$ & $\mathbf{\%}$ \\
\hline Jiang [20] & 1 & 1 & 1 & 1 & 1 & 1 & 1 & 1 & 1 & 1 & 1 & 0.75 & 1 & 1 & 1 & 1 & 1 & 1 & 1 & 0 & 0.8 & 1 & 1 & 0.5 & 1 & 22.5 & 90 \\
\hline Gao [21] & 0 & 1 & 1 & 1 & 1 & 1 & 0 & 0.5 & 0 & 0.5 & 0.5 & 1 & 1 & 0.5 & 0.5 & 1 & 1 & NA & 0.5 & 0 & 1 & 1 & 0 & 0 & 1 & 15 & 62 \\
\hline Liu [22] & 1 & 1 & 1 & 1 & 1 & 1 & 1 & 1 & 1 & 1 & 1 & 1 & 1 & 0.5 & 1 & 1 & 1 & 1 & 1 & 1 & 1 & 1 & 1 & 1 & 1 & 24.5 & 98 \\
\hline Gianotti [23] & 1 & 1 & 0.5 & 1 & 1 & 0.5 & 0 & 1 & 1 & 1 & 1 & 1 & 1 & 0 & 1 & 1 & 0.5 & NA & 0 & 1 & 1 & 1 & 1 & 0 & 1 & 18.5 & 77 \\
\hline Worthley [24] & 0 & 0.5 & 0.5 & 1 & 1 & 0.5 & 0 & 0 & 0 & 1 & 0.5 & 1 & 0.5 & 0 & 0 & 1 & 0.5 & NA & 1 & 1 & 1 & 1 & 1 & 1 & 1 & 15 & 62 \\
\hline Lacouture [26] & 0.5 & 1 & 1 & 0.5 & 1 & 1 & 0.5 & 0 & 0 & 0 & 0.5 & 1 & 0.75 & 0 & 1 & 1 & 0.5 & 1 & 1 & 0 & 1 & 1 & 1 & 0 & 1 & 16.2 & 65 \\
\hline Hegazy [27] & 0.5 & 1 & 0.5 & 1 & 1 & 0.5 & 0 & 0 & 0 & 0 & 0 & 0.5 & 0 & 0 & 1 & 1 & 0.5 & 1 & 0 & 0 & 1 & 0.5 & 0 & 0 & 0 & 9.5 & 38 \\
\hline Groeger [28] & 0.5 & 1 & 0.5 & 1 & 1 & 0.5 & 0 & 0 & 0 & 1 & 0.5 & 1 & 0 & 0 & 0 & 1 & 0.5 & NA & 0 & 0 & 1 & 1 & 0 & 0 & 0 & 10.5 & 44 \\
\hline Sharma [29] & 1 & 1 & 1 & 1 & 1 & 1 & 0.5 & 1 & 1 & 1 & 1 & 0.5 & 1 & 0.5 & 1 & 1 & 0.5 & 1 & 1 & 0 & 1 & 1 & 1 & 1 & 1 & 22 & 88 \\
\hline De Sanctis [30] & 0.5 & 1 & 1 & 1 & 1 & 1 & 1 & 1 & 0 & 1 & $\mathrm{NA}$ & 1 & 0.75 & 1 & 1 & 1 & 0.5 & 1 & 1 & 1 & 0.5 & 1 & 1 & 0 & 1 & 20.2 & 84 \\
\hline Consoli [31] & 1 & 1 & 1 & 1 & 1 & 1 & 1 & 1 & 1 & 1 & $\mathrm{NA}$ & 0.5 & 1 & 0 & 1 & 1 & 0.5 & $\mathrm{NA}$ & 1 & 1 & 1 & 1 & 1 & 0 & 1 & 20 & 87 \\
\hline Wada [32] & 0.5 & 1 & 1 & 1 & 1 & 1 & 0 & 0.5 & 0 & 0 & 0 & 1 & 0.5 & 1 & 0.5 & 1 & 0.5 & 1 & 1 & 1 & 0.5 & 1 & 0 & 0 & 0 & 14 & 56 \\
\hline Mangell [33] & 0.5 & 1 & 1 & 1 & 1 & 0.5 & 1 & 0 & 1 & 1 & 0.5 & 0.5 & 0.5 & 0 & 1 & 1 & 0.5 & NA & 1 & 1 & 0.5 & 1 & 0 & 0 & 1 & 16.5 & 69 \\
\hline Ouwehand [34] & 0.5 & 1 & 1 & 1 & 1 & 0.5 & 0 & 0 & 0 & 1 & 0.5 & 0.5 & 0.5 & 0 & 1 & 1 & 1 & 1 & 0 & 0 & 1 & 1 & 0 & 0 & 1 & 14.5 & 58 \\
\hline Friederich [25] & 0.5 & 1 & 0.5 & 1 & 1 & 0.5 & 0 & 0 & 0 & 1 & 0 & 0.5 & 0.5 & 0.5 & 1 & 1 & 0.5 & 1 & 1 & 1 & 1 & 1 & 0 & 1 & 1 & 16 & 64 \\
\hline
\end{tabular}


Most of the studies were randomized placebo controlled clinical trials (14; 93\%) [20-24,26-34]. Two studies, a triple cohort study with published results of two cohorts [26] and a pilot study [25], stand out. The origin of the studies was varied with a slight predominance of Asian countries, such as China [20-22], Japan [32], and India [29], (five studies), and the rest were distributed in different countries like Italy (two studies) [23,30] and Brazil [31], Netherlands [25], Australian [24] Ireland [28], Egypt [27], Sweden [33] and Finland [34] with one study each one. A multicenter study in the USA and Republic of Korea stands out [26].

On average, the age of the population included in the studies was between 6.5 and 72 years and the number of subjects per study oscillated between 20 [24] and 173 [26]. Regarding the distribution by sex, it was observed that male sex prevailed [20-27,29-31,33]. In one study [28] the sex of the participants was not specified.

Most studied pathologies were colorectal cancer (CRC) [21-23], concurrent chemoradiotherapy (CCRT) [20] resection colon (RC) [31,33], non-small cell lung cancer (NSCLC) [26] head and neck cancer (HNC) $[29,30]$, ulcerative colitis (UC) $[27,28]$ affecting mucous membranes and both oral mucositis $(\mathrm{OM})$ and gastrointestinal mucositis (GIM). Also, biomarkers of inflammation and cytokine levels in gastrointestinal and extra-intestinal inflammatory disorders [28] or in the context of colorectal carcinogenesis [24] were assessed in healthy volunteers. The follow-up period in the selected works ranged between five days before rectal colon surgery [21] and 39 months [30] after CCRT.

The intervention applied was very similar in all studies, as their main objective was to determine, mainly, the influence of probiotic intake on the intestinal microbiota and on different symptoms such as mucositis, diarrhea, and bacterial translocation in patients undergoing different radio and chemotherapy treatments. One study [24] used healthy patients to assess probiotic intake and characterized the luminal and biological consequences of these supplements in the context of colorectal carcinogenesis.

The probiotics used in the different interventions were, mainly, gram positive bacteria of the genus Bifidobacterium and Lactobacillus, highlighting the species B. longum, B. infantis, B. breve, and B. lactis and L. acidophillus, L. plantarum, L. johnsonii, L. delbrueckii, L. fermentum, and, L. lactis, [20-24,32-34], respectively. Other species of the Enterococcus genus, E. faecium, and E. faecalis [20,21] were part of the intervention. In one study, unlike the rest, the probiotic used was the yeast Saccharomyces boulardii [31]. The VSL\#3 trademark, composed of four Lactobacilli species; L. plantarum, L. casei, L. acidophilus, and L. delbrueckii subspecies bulgaricus, three Bifidobacteria species; B. infantis, B. longum, and B. breve, and one Streptococci species; Streptococcus salivarus subespecies thermophilus, was also used in two studies $[25,26]$. In some studies, the probiotics were combined with prebiotics such as: High-amylose maize starch (HAMS) [24] and lactitol [34].

\subsection{Probiotics and Healthy People}

Among the studies selected in this review, two of them [24,34] showed that probiotic consumption by healthy people could play a protective role. In one of the studies, consumption of $B$. animalis lactis and resistant starch has modified the intestinal microbiota of healthy subjects increasing the abundance of species that, at least in mouse, are protective against intestinal tumorigenesis [24]. In the other one, administration of Lactobacillus acidophilus strain combined with lactitol to healthy elderly has improved intestinal microbiota health and immune parameters as seen by an increase of Bifidobacterium species, spermidine, $\mathrm{PGE}_{2}$ and IgA in faecal samples [34].

\subsection{Probiotics and $C R C$}

Four of the selected studies [21-23,31] showed the protective effect of probiotics administration in colorectal cancer patients who underwent surgery. Gao et al. [21], have shown that the colonic microbiota of these patients was less abundant and rich that the one of healthy subjects and that the administration of Bifidobacterium longum, Lactobacillus acidophilus, and Enterococcus faecalis for five days, partially prevented the observed dysbiosis, increased the abundance of beneficial bacteria, and decreased the number of some pathogenic ones including species of the genus Fusobacterium that 
have been proposed as a contributing factor for CRC development. In the study by Gianotti et al. [23], treatment with different doses of two probiotics, Bifidobacterium longum and Lactobacillus johnsonii, led, in a dose dependent way, to a decrease of pathogenic microorganisms, both in colonic mucosa and faecal samples, and an increase in CD3+, CD4+, and CD8+ T lymphocytes, suggesting a better protection of probiotic treated patients against possible infections. In their study, Liu et al. [22], showed that the administration of three probiotics, Lactobacillus plantarum, Lactobacillus acidophilus, and Bifidobacterium longum, for sixteen days increased the diversity and abundance of the faecal microbiota, improved the integrity of the intestinal mucosa and decreased possible postoperative clinical complications, such as diarrhea and infections. Finally, Consoli et al. [31] observed in patients undergoing colon resection that the administration of Saccharomyces boulardii for one week decreased the mucosa expression of proinflammatory cytokines IL-1 $\beta$ and IL-23A and the incidence rate of postoperative infections ( $38.8 \%$ in the placebo group versus $13.3 \%$ in the probiotic group). However, probiotic treatments do not always improve the conditions of these patients as shown in the study by Mangel et al. [33]. The authors treated patients with a single probiotic, Lactobacillus plantarum $299 \mathrm{v}$ for 13 days, and this treatment didn't decrease bacterial translocation or postoperative complications. The fact that this species has been successfully used by Liu et al. [22], when combined with other probiotics suggests that either the strain $299 \mathrm{v}$ is not efficient or that this species has no effect when used alone.

\subsection{Probiotics and Mucositis}

Several of the selected studies showed that probiotics can decrease the incidence rate of mucositis induced by radio and/or chemotherapy and attenuate its symptoms in patients with different kind of cancer.

In the study by Jiang et al. [20], the incidence rate and severity of oral mucositis induced by chemo and radiotherapy in patients with nasal pharyngeal carcinoma was decreased by the administration, during the whole treatment, of Bifidobacterium longum, Lactobacillus lactis, and Enterococcus faecium. The results suggest that the probiotics attenuated the dysbiosis and the decrease of T type lymphocytes induced by the radiotherapy. Wada et al. [32], has shown in hematological malignancies patients treated with chemotherapy, that the administration of Bifidobacterium breve strain Yakult tended to decrease the incidence and severity of different adverse effects such as fever, diarrhea, and days of antibiotic treatment. In a clinical trial with patients with squamous cell carcinoma of the head and neck treated with radiotherapy, Sharma et al. [29] reported that the administration of Lactobacillus brevis CD2 reduced the incidence of grade 3 and 4 oral mucositis (52\% incidence in the probiotic group versus $77 \%$ in the placebo group). However, De Sanctis et al. [30], found in a similar study (same type of patients treated with radiotherapy) that the same probiotic treatment had no effect. The fact that De Sanctis et al. [30], took a smaller sample size than Sharma et al. [29], 75 subjects instead of 200, and that they applied a less aggressive radiotherapy, that induced a lower rate of grade 3 and 4 oral mucositis, could explain the lack of effect observed by these authors.

\subsection{Probiotics and Other Intestinal Pathologies}

The anti-inflammatory effect of probiotics has been shown in other pathologies with a clear inflammation component including intestinal pathologies as ulcerative colitis and Crohn's disease. As an example, Hegazy et al. [27], have shown that the administration of Lactobacillus delbrueckii and Lactobacillus fermentum to ulcerative colitis patients decreased the recruitment of leukocytes to the colonic mucosa and the expression levels of different colonic inflammatory cytokines such as IL-6, TNF- $\alpha$, or NF-kB p65. In another study, Groeger et al. [28], have shown a similar effect with Bifidobacterium infantis in three different pathologies namely, ulcerative colitis, psoriasis, and chronic fatigue syndrome (CFS). In the three cases, but not in the same way, treatment with the probiotic decreased serum levels of several proinflammatory cytokines such as IL-6, TNF- $\alpha$, or C-reactive protein $(\mathrm{CRP})$. 


\section{Discussion}

The study of the current events/obsolescence of the chosen topic presents a moderate validity, since, from all documents that could be recovered, $40 \%$ of the articles have been published in the last seven years; Burton Kebler's index presented a value appropriate to the expected one, while Price's index obtained a slightly lower than expected value in the area of health science [35].

On the other hand, according to the degree of evidence and recommendation of the U.S. Preventive Services Task Force (USPSTF) [36], the controlled and randomized clinical trials (CRCT) provide the most scientific evidence for their consistent cause-and-effect relationship. The evaluation of the quality of the studies included in this review through CONSORT was acceptable with an average of 17 out of 25 .

Likewise, English is the language chosen for the publication of most articles as doing so in a different language has a negative on the impact factor and quotations [37]. In addition, the number of English-speaking journals contained in databases is currently very high [38]. Regarding the population included in the studies was heterogeneous and mostly adult with the exception of the one of Wada et al. [32] who were children.

There is high interest in improving mucositis symptomatology because it represents a health problem affecting more than two million people worldwide each year [39]. Reinforcing the possible use of probiotics in mucositis, several studies have shown its effectiveness in the prevention or treatment of two other important features of mucositis namely diarrhea and an increased intestinal permeability.

Probiotics antidiarrheal effect is very well established being probably one of their best-known effects. They are effective in the prevention and/or attenuation of practically all types of diarrheas including diarrhea associated with rotavirus infection in children, acute diarrhea in children and adults, antibiotic-associated diarrhea, travellers' diarrhea, or AIDS-associated diarrhea [40-45]. Although less well known and established, a growing number of studies, besides the one by Liu et al. [22], is showing that probiotics can enhance the intestinal permeability barrier. This has been shown, for instance, in children with Crohn's disease [46] and in different groups of elite athletes [47-49].

Probiotics can also prevent or attenuate other gastrointestinal mucositis symptoms as nausea, vomiting, and abdominal pain. This effect has been widely reported when they have been used as adjuvant in treatments against Helicobacter pylori, mainly based in the use of antibiotics and proton pump inhibitors, that frequently cause the aforementioned side effects [50-55].

In agreement with these results, probiotics have successfully been used to prevent mucositis symptoms in animal models. In mice, administration of Lactobacillus casei rhamnosus [56]. Saccharomyces boulardii [57], Lactobacillus acidophilus [58], or Bifidobacterium bifidum [59] has decreased the mucositis induced by 5 -Fluorouracil (5-FU) and a similar effect was observed in rats by the administration of either a combination of Bifidobacterium breve, Lactobacillus acidophilus, Lactobacillus casei, and Streptococcus thermophilus [60] or Bifidobacterium infantis alone [61,62]. Also, in rats, the administration of the probiotic mix VSL\#3 has reduced the incidence and severity of irinotecan-induced diarrhea [63].

The fact that in the studies analysed in this review at least 13 different species of bacteria and one yeast species have been successfully used, either alone or in different combinations, suggests that not only a single specific strain or one single combination of probiotics is going to work but rather many combinations could be a good treatment option. In order to select the appropriate combination of strains, important factors should be considered as the fact that not all the combinations are able to prevent the adverse effects induced by all the treatments. In this sense, Lacouture et al. [26], showed, that the administration of the probiotic combination VSL\#3 to advanced non-small cell lung cancer patients was unable to prevent the mucositis and the diarrhea induced by dacomitinib, a pan-human epidermal growth factor receptor (HER) inhibitor. Another important factor to be considered is the possible interference between the probiotic and different components of the patient's treatment. Although their results were not statistically significant, Friederich et al. [25], showed that whereas either a treatment with a symbiotic (VSL\#3 and inulin) or sulindac (a non-steroidal anti-inflammatory) 
increased Glutathione S-transferase (GST) activity and decreased proliferation rates at the colonic mucosa, the combination of both treatments had the opposite effects.

The most frequently used probiotic in our selected studies, is Bifidobacterium longum. Always combined with other probiotics, it has successfully been used in four studies, three of them in patients undergoing colorectal surgery [21-23] and the other one in patients with nasal pharyngeal carcinoma treated with chemo and radiotherapy [20]. Mixes containing this probiotic have had several positive effects as the restoration of a normal microbiota, immune response modulation, an enhancement of the intestinal barrier and a decrease of postoperative clinical complications as diarrhea and infections.

Lactobacillus acidophilus has been the second most frequently used probiotic. It has been successfully used either alone, one study [34] with healthy subjects, or combined with other two strains, two studies [21,22] with subjects undergoing colorectal surgery. When combined with other probiotics, one of them was always Bifidobacterium longum, suggesting that, when used together, these two species seem to be efficient in mucositis prevention.

Two species, Lactobacillus plantarum and Lactobacillus brevis, have been used two times. When L. plantarum was used alone in patients undergoing colon resection it had no effect in the prevention of postoperative complications [33]. Only when combined with B. longum and L. acidophilus in patients undergoing surgery, its administration was efficient restoring a normal microbiota, decreasing the intestinal permeability, and preventing postoperative complications [22]. As these effects have been observed whenever B. longum and L. acidophilus are used together, it is not clear if L. plantarum had any effect at all.

An identical treatment with the strain L. brevis CD2 has been used in two studies with squamous cell carcinoma of the head and neck patients undergoing radiotherapy. Whereas in one of the studies [29] the treatment successfully decreased the incidence rate of grade 3 and 4 mucositis, in the other one was totally ineffective [30]. Although the number of patients and the applied radiotherapy was different between both studies, the disagreement between the results shows that this probiotic is not always effective.

Ten probiotics have only been tested once. Six of them (Lactobacillus lactis, Enterococcus faecium, Enterococcus faecalis, Lactobacillus johnsonii, Lactobacillus delbrueckii, and Lactobacillus fermentum) have been used in combination with other strains making almost impossible to guess their specific contribution to the observed effects. In addition, two of these species, E. faecium and E. faecalis are potentially pathogenic and are not included in the Qualified Presumption of Safety (QPS) list as the European Food Safety Authority (EFSA) do not recommend the inclusion of Enterococci species in this list [64]. The other four (Bifidobacterium animalis sub. Lactis, Bifidobacterium breve, Bifidobacterium infantis and Saccharomyces boulardii) have been tested alone. B. animalis sub. lactis, has been only used in healthy subjects and shown to modify the gut microbiota composition but only when combined with a prebiotic [24]. Treatment with the other three probiotics has successfully decreased mucositis related symptoms either in cancer patients or in other pathologies. B. breve has decreased adverse effects of chemotherapy treatment, such as fever, diarrhea, and antibiotics consumption in patients with hematologic tumors [32]; B. infantis, has decreased serum levels of proinflammatory cytokines in patients with ulcerative colitis, psoriasis, or chronic fatigue syndrome [28]; and S. boulardii, has decreased colonic mucosa expression of proinflammatory cytokines and decreased postoperative infections [31].

There are possible limitations on the revised essays and the results have to be considered cautiously. For instance, the follow-up period, was not long enough in some cases, between five days and eight weeks [20-23,25-28,31,32,34], insufficient time to assess the results [65]. In the studies of Gao et al. [21], and Worthley et al. [24], the number of patients was less than 30, so the results obtained could lack the expected scientific rigor. 


\section{Conclusions}

However, despite the limitations, the results of the studies included in this review show that probiotics have been used in different types of cancer patients and they have had a plethora of positive effects including a decrease of the inflammation, the modulation of the immune system, an improved composition of the gut microbiota, with more beneficial bacterial species and less pathogenic ones, and an improvement of the intestinal barrier function. Importantly, they have practically produced no adverse effects.

Thus, probiotics seem to be perfect candidates to ameliorate mucositis in cancer patients, but in order to improve their effectiveness, more clinical trials are needed. It is important to define which probiotic or combination of probiotics is the best one for each type of cancer therapy, discard possible interferences with other components of the treatment and to determine, in each case, which is the best posology.

Taking into account these results, we suggest that a combination of Biffidobacterium longum, Lactobacillus acidophilus, Biffidobacterium breve, Biffidobacterium infantis, and Saccharomyces boulardii could be a good combination of probiotics to reduce incident rates of mucositis or ameliorate its symptoms in chemo or radiotherapy treated patients, and would be worth being tested in a clinical trial.

We made this suggestion cautiously considering that a lot of data exist about probiotics and mucositis and that, only based on these data, no conclusion can be drawn regarding the superiority of any one particular organism or combination of organisms. Therefore, in this field, there is a good opportunity and a need to develop further investigations

Author Contributions: J.A.P.-M. and J.M.M.-A. equally contributed in the preparation of this manuscript: Conceptualization, methodology, bibliography data search, information processing, final selection of articles, data extraction and manuscript preparation.

Funding: This research did not receive external funding or financial compensation

Acknowledgments: Thanks to Korott, s.l. especially, to José Manuel Pérez Orquín and Javier Blanes Puig, for its continuous support to the authors during the preparation of this manuscript.

Conflicts of Interest: The authors declare no conflict of interest.

\section{References}

1. Touchefeu, Y.; Montassier, E.; Nieman, K.; Gastinne, T.; Potel, G.; Bruley Des Varannes, S.; Le Vacon, F.; de La Cochetière, M.F. Systematic review: The role of the gut microbiota in chemotherapyor radiation-induced gastrointestinal mucositis-Current evidence and potential clinical applications. Aliment. Pharmacol. Ther. 2014, 40, 409-421. [CrossRef] [PubMed]

2. Jones, J.A.; Avritscher, E.B.C.; Cooksley, C.D.; Michelet, M.; Bekele, B.N.; Elting, L.S. Epidemiology of treatment-associated mucosal injury after treatment with newer regimens for lymphoma, breast, lung, or colorectal cancer. Support Care Cancer 2006, 14, 505-515. [CrossRef] [PubMed]

3. Vera-Llonch, M.; Oster, G.; Hagiwara, M.; Sonis, S. Oral mucositis in patients undergoing radiation treatment for head and neck carcinoma. Cancer 2006, 106, 329-336. [CrossRef] [PubMed]

4. Vera-Llonch, M.; Oster, G.; Ford, C.M.; Lu, J.; Sonis, S. Oral mucositis and outcomes of allogeneic hematopoietic stem-cell transplantation in patients with hematologic malignancies. Support Care Cancer 2007, 15, 491-496. [CrossRef] [PubMed]

5. Sonis, S.T. The pathobiology of mucositis. Nat. Rev. Cancer 2004, 4, 277-284. [CrossRef] [PubMed]

6. Criswell, T.; Leskov, K.; Miyamoto, S.; Luo, G.; Boothman, D.A. Transcription factors activated in mammalian cells after clinically relevant doses of ionizing radiation. Oncogene 2003, 22, 5813-5827. [CrossRef]

7. Bamba, S.; Andoh, A.; Yasui, H.; Araki, Y.; Bamba, T.; Fujiyama, Y. Matrix metalloproteinase-3 secretion from human colonic subepithelial myofibroblasts: Role of interleukin-17. J. Gastroenterol. 2003, 38, 548-554. [CrossRef] [PubMed]

8. Naidu, M.U.R.; Ramana, G.V.; Rani, P.U.; Mohan, I.K.; Suman, A.; Roy, P. Chemotherapy-induced and/or radiation therapy-induced oral mucositis-complicating the treatment of cancer. Neoplasia (N. Y.) 2004, 6, 423-431. [CrossRef] 
9. Elting, L.S.; Cooksley, C.; Chambers, M.; Cantor, S.B.; Manzullo, E.; Rubenstein, E.B. The burdens of cancer therapy. Clinical and economic outcomes of chemotherapy-induced mucositis. Cancer 2003, 98, 1531-1539. [CrossRef] [PubMed]

10. Trotti, A.; Bellm, L.A.; Epstein, J.B.; Frame, D.; Fuchs, H.J.; Gwede, C.K.; Komaroff, E.; Nalysnyk, L.; Zilberberg, M.D. Mucositis incidence, severity and associated outcomes in patients with head and neck cancer receiving radiotherapy with or without chemotherapy: A systematic literature review. Radiother. Oncol. 2003, 66, 253-262. [CrossRef]

11. Elting, L.S.; Cooksley, C.D.; Chambers, M.S.; Garden, A.S. Risk, outcomes, and costs of radiation-induced oral mucositis among patients with head-and-neck malignancies. Int. J. Radiat. Oncol. Biol. Phys. 2007, 68, 1110-1120. [CrossRef] [PubMed]

12. Villa, A.; Sonis, S.T. Mucositis: Pathobiology and management. Curr. Opin. Oncol. 2015, 27, 159-164. [CrossRef] [PubMed]

13. Blennow, O.; Ljungman, P.; Sparrelid, E.; Mattsson, J.; Remberger, M. Incidence, risk factors, and outcome of bloodstream infections during the pre-engraftment phase in 521 allogeneic hematopoietic stem cell transplantations. Transpl. Infect. Dis. 2014, 16, 106-114. [CrossRef] [PubMed]

14. Mego, M.; Holec, V.; Drgona, L.; Hainova, K.; Ciernikova, S.; Zajac, V. Probiotic bacteria in cancer patients undergoing chemotherapy and radiation therapy. Complement. Ther. Med. 2013, 21, 712-723. [CrossRef] [PubMed]

15. Food and Agriculture Organization of the United Nations; World Health Organization. Probiotics in Food: Health and Nutritional Properties and Guidelines for Evaluation; FAO food and nutrition paper; Food and Agriculture Organization of the United Nations: Rome, Italy; World Health Organization: Geneva, Switzerland, 2006; p. 50.

16. Byakika, S.; Mukisa, I.; Byenkya, Y.; Muyanja, C.; Byenkya Byaruhanga, Y. A Review of Criteria and Methods for Evaluating the Probiotic Potential of Microorganisms. Food Rev. Int. 2019, 427-466. [CrossRef]

17. Wanden-Berghe, C.; Sanz-Valero, J. Systematic reviews in nutrition: Standardized methodology. Br. J. Nutr. 2012, 107 (Suppl. 2), S3-S7. [CrossRef] [PubMed]

18. Eldridge, S.M.; Chan, C.L.; Campbell, M.J.; Bond, C.M.; Hopewell, S.; Thabane, L.; Lancaster, G.A. CONSORT 2010 statement: Extension to randomised pilot and feasibility trials. BMJ 2016, 355, i5239. [CrossRef] [PubMed]

19. Moher, D.; Liberati, A.; Tetzlaff, J.; Altman, D.G.; PRISMA Group. Preferred reporting items for systematic reviews and meta-analyses: The PRISMA statement. PLoS Med. 2009, 6, e1000097. [CrossRef]

20. Jiang, C.; Wang, H.; Xia, C.; Dong, Q.; Chen, E.; Qiu, Y.; Su, Y.; Xie, H.; Zeng, L.; Kuang, J.; et al. A randomized, double-blind, placebo-controlled trial of probiotics to reduce the severity of oral mucositis induced by chemoradiotherapy for patients with nasopharyngeal carcinoma. Cancer 2019, 125, 1081-1090. [CrossRef]

21. Gao, Z.; Guo, B.; Gao, R.; Zhu, Q.; Wu, W.; Qin, H. Probiotics modify human intestinal mucosa-associated microbiota in patients with colorectal cancer. Mol. Med. Rep. 2015, 12, 6119-6127. [CrossRef]

22. Liu, Z.; Qin, H.; Yang, Z.; Xia, Y.; Liu, W.; Yang, J.; Zhang, H.; Yang, Z.; Wang, Y.; Zheng, Q. Randomised clinical trial: The effects of perioperative probiotic treatment on barrier function and post-operative infectious complications in colorectal cancer surgery-a double-blind study. Aliment. Pharmacol. Ther. 2011, 33, 50-63. [CrossRef] [PubMed]

23. Gianotti, L.; Morelli, L.; Galbiati, F.; Rocchetti, S.; Coppola, S.; Beneduce, A.; Gilardini, C.; Zonenschain, D.; Nespoli, A.; Braga, M. A randomized double-blind trial on perioperative administration of probiotics in colorectal cancer patients. World J. Gastroenterol. 2010, 16, 167-175. [CrossRef] [PubMed]

24. Worthley, D.; Le Leu, R.; Whitehall, V.; Conlon, M.; Christophersen, C.; Belobrajdic, D.; Mallitt, K.A.; Hu, Y.; Irahara, N.; Ogino, S.; et al. A human, double-blind, placebo-controlled, crossover trial of prebiotic, probiotic, and synbiotic supplementation: Effects on luminal, inflammatory, epigenetic, and epithelial biomarkers of colorectal cancer. Am. J. Clin. Nutr. 2009, 90, 578-586. [CrossRef] [PubMed]

25. Friederich, P.; Verschuur, J.; van Heumen, B.; Roelofs, H.; Berkhout, M.; Nagtegaal, I.D.; van Oijen, M.G.H.; van Krieken, J.H.J.M.; Peters, W.H.M.; Nagengast, F.M. Effects of intervention with sulindac and inulin/VSL\#3 on mucosal and luminal factors in the pouch of patients with familial adenomatous polyposis. Int. J. Colorectal. Dis. 2011, 26, 575-582. [CrossRef] [PubMed] 
26. Lacouture, M.; Keefe, D.; Sonis, S.; Jatoi, A.; Gernhardt, D.; Wang, T.; Doherty, J.P.; Giri, N.; Nadanaciva, S.; O'Connell, J.; et al. A phase II study (ARCHER 1042) to evaluate prophylactic treatment of dacomitinib-induced dermatologic and gastrointestinal adverse events in advanced non-small-cell lung cancer. Ann. Oncol. 2016, 27, 1712-1718. [CrossRef] [PubMed]

27. Hegazy, S.; El-Bedewy, M. Effect of probiotics on pro-inflammatory cytokines and NF-kappaB activation in ulcerative colitis. World J. Gastroenterol. 2010, 16, 4145-4151. [CrossRef] [PubMed]

28. Groeger, D.; O’Mahony, L.; Murphy, E.F.; Bourke, J.F.; Dinan, T.G.; Kiely, B.; Shanahan, F.; Quigley, E.M. Bifidobacterium infantis 35624 modulates host inflammatory processes beyond the gut. Gut Microbes 2013, 4, 325-339. [CrossRef] [PubMed]

29. Sharma, A.; Rath, G.K.; Chaudhary, S.P.; Thakar, A.; Mohanti, B.K.; Bahadur, S. Lactobacillus brevis CD2 lozenges reduce radiation- and chemotherapy-induced mucositis in patients with head and neck cancer: A randomized double-blind placebo-controlled study. Eur. J. Cancer (Oxf. Engl. 1990) 2012, 48, 875-881. [CrossRef] [PubMed]

30. DESanctis, V.; Belgioia, L.; Cante, D.; LAPorta, M.; Caspiani, O.; Guarnaccia, R.; Argenone, A.; Muto, P.; Musio, D.; DEFelice, F.; et al. Lactobacillus brevis CD2 for Prevention of Oral Mucositis in Patients With Head and Neck Tumors: A Multicentric Randomized Study. Anticancer Res. 2019, 39, 1935-1942. [CrossRef] [PubMed]

31. Consoli, M.; Da Silva, R.; Nicoli, J.; Bruna-Romero, O.; Da Silva, R.; De Vasconcelos Generoso, S.; Correia, M.I. Randomized Clinical Trial: Impact of Oral Administration of Saccharomyces boulardii on Gene Expression of Intestinal Cytokines in Patients Undergoing Colon Resection. J. Parenter. Enter. Nutr. 2016, 40, 1114-1121. [CrossRef] [PubMed]

32. Wada, M.; Nagata, S.; Saito, M.; Shimizu, T.; Yamashiro, Y.; Matsuki, T.; Asahara, T.; Nomoto, K. Effects of the enteral administration of Bifidobacterium breve on patients undergoing chemotherapy for pediatric malignancies. Support Care Cancer 2010, 18, 751-759. [CrossRef] [PubMed]

33. Mangell, P.; Thorlacius, H.; Syk, I.; Ahrné, S.; Molin, G.; Olsson, C.; Jeppsson, B. Lactobacillus plantarum 299v does not reduce enteric bacteria or bacterial translocation in patients undergoing colon resection. Dig. Dis. Sci. 2012, 57, 1915-1924. [CrossRef] [PubMed]

34. Ouwehand, A.; Tiihonen, K.; Saarinen, M.; Putaala, H.; Rautonen, N. Influence of a combination of Lactobacillus acidophilus NCFM and lactitol on healthy elderly: Intestinal and immune parameters. Br. J. Nutr. 2009, 101, 367-375. [CrossRef] [PubMed]

35. Tomás-Casterá, V.; Sanz-Valero, J.; Juan-Quilis, V. Estudio bibliométrico de la producción científica y de consumo de las revistas sobre nutrición indizadas en la red SciELO. Nutr. Hosp. 2013, 28, 969-970. [CrossRef] [PubMed]

36. Manterola, C.; Asenjo-Lobos, C.; Otzen, T. Jerarquización de la evidencia: Niveles de evidencia y grados de recomendación de uso actual. Rev. Chil. Infectol. 2014, 31, 705-718. [CrossRef] [PubMed]

37. Franco-Lopez, A.; Sanz-Valero, J.; Culebras, J.M. Publicar en castellano, o en cualquier otro idioma que no sea inglés, negativo para el factor de impacto y citaciones. J. Negat. No Posit. Results 2016, 1, 65-70. [CrossRef]

38. Sanz-Valero, J.; Gil, Á.; Wanden-Berghe, C.; Martínez de Victoria, E. Análisis bibliométrico y temático de la producción científica sobre ácidos grasos omega-3 indizada en las bases de datos internacionales sobre ciencias de la salud. Nutr. Hosp. 2012, 27, 41-48. [CrossRef]

39. Gibson, R.J.; Keefe, D.M.K.; Lalla, R.V.; Bateman, E.; Blijlevens, N.; Fijlstra, M.; King, E.E.; Stringer, A.M.; van der Velden, W.J.; Yazbeck, R.; et al. Systematic review of agents for the management of gastrointestinal mucositis in cancer patients. Support Care Cancer 2013, 21, 313-326. [CrossRef]

40. Buts, J.P.; De Keyser, N. Effects of Saccharomyces boulardii on intestinal mucosa. Dig. Dis. Sci. 2006, 51, 1485-1492. [CrossRef]

41. Sazawal, S.; Hiremath, G.; Dhingra, U.; Malik, P.; Deb, S.; Black, R.E. Efficacy of probiotics in prevention of acute diarrhoea: A meta-analysis of masked, randomised, placebo-controlled trials. Lancet Infect. Dis. 2006, 6, 374-382. [CrossRef]

42. Szajewska, H.; Skórka, A.; Dylag, M. Meta-analysis: Saccharomyces boulardii for treating acute diarrhoea in children. Aliment. Pharmacol. Ther. 2007, 25, 257-264. [CrossRef] [PubMed]

43. Szajewska, H.; Skórka, A.; Ruszczyński, M.; Gieruszczak-Białek, D. Meta-analysis: Lactobacillus GG for treating acute diarrhoea in children. Aliment. Pharmacol. Ther. 2007, 25, 871-881. [CrossRef] [PubMed] 
44. Hayes, S.R.; Vargas, A.J. Probiotics for the Prevention of Pediatric Antibiotic-Associated Diarrhea. Explore (N. Y.) 2016, 12, 463-466. [CrossRef] [PubMed]

45. Cai, J.; Zhao, C.; Du, Y.; Zhang, Y.; Zhao, M.; Zhao, Q. Comparative efficacy and tolerability of probiotics for antibiotic-associated diarrhea: Systematic review with network meta-analysis. United Eur. Gastroenterol. J. 2018, 6, 169-180. [CrossRef] [PubMed]

46. Gupta, P.; Andrew, H.; Kirschner, B.S.; Guandalini, S. Is lactobacillus GG helpful in children with Crohn's disease? Results of a preliminary, open-label study. J. Pediatr. Gastroenterol. Nutr. 2000, 31, 453-457. [CrossRef] [PubMed]

47. Lamprecht, M.; Bogner, S.; Schippinger, G.; Steinbauer, K.; Fankhauser, F.; Hallstroem, S.; Schuetz, B.; Greilberger, J.F. Probiotic supplementation affects markers of intestinal barrier, oxidation, and inflammation in trained men; a randomized, double-blinded, placebo-controlled trial. J. Int. Soc. Sports Nutr. 2012, 9, 45. [CrossRef] [PubMed]

48. Roberts, J.D.; Suckling, C.A.; Peedle, G.Y.; Murphy, J.A.; Dawkins, T.G.; Roberts, M.G. An Exploratory Investigation of Endotoxin Levels in Novice Long Distance Triathletes, and the Effects of a Multi-Strain Probiotic/Prebiotic, Antioxidant Intervention. Nutrients 2016, 8, 733. [CrossRef]

49. Shing, C.M.; Peake, J.M.; Lim, C.L.; Briskey, D.; Walsh, N.P.; Fortes, M.B.; Ahuja, K.D.; Vitetta, L. Effects of probiotics supplementation on gastrointestinal permeability, inflammation and exercise performance in the heat. Eur. J. Appl. Physiol. 2014, 114, 93-103. [CrossRef]

50. Cremonini, F.; Di Caro, S.; Covino, M.; Armuzzi, A.; Gabrielli, M.; Santarelli, L.; Nista, E.C.; Cammarota, G.; Gasbarrini, G.; Gasbarrini, A. Effect of different probiotic preparations on anti-helicobacter pylori therapy-related side effects: A parallel group, triple blind, placebo-controlled study. Am. J. Gastroenterol. 2002, 97, 2744-2749. [CrossRef]

51. Armuzzi, A.; Cremonini, F.; Bartolozzi, F.; Canducci, F.; Candelli, M.; Ojetti, V.; Cammarota, G.; Anti, M.; De Lorenzo, A.; Pola, P.; et al. The effect of oral administration of Lactobacillus GG on antibiotic-associated gastrointestinal side-effects during Helicobacter pylori eradication therapy. Aliment. Pharmacol. Ther. 2001, 15, 163-169. [CrossRef]

52. Nista, E.C.; Candelli, M.; Cremonini, F.; Cazzato, I.A.; Zocco, M.A.; Franceschi, F.; Cammarota, G.; Gasbarrini, G.; Gasbarrini, A. Bacillus clausii therapy to reduce side-effects of anti-Helicobacter pylori treatment: Randomized, double-blind, placebo controlled trial. Aliment. Pharmacol. Ther. 2004, 20, 1181-1188. [CrossRef] [PubMed]

53. Tolone, S.; Pellino, V.; Vitaliti, G.; Lanzafame, A.; Tolone, C. Evaluation of Helicobacter Pylori eradication in pediatric patients by triple therapy plus lactoferrin and probiotics compared to triple therapy alone. Ital. J. Pediatr. 2012, 38, 63. [CrossRef]

54. Ahmad, K.; Fatemeh, F.; Mehri, N.; Maryam, S. Probiotics for the treatment of pediatric helicobacter pylori infection: A randomized double blind clinical trial. Iran. J. Pediatr. 2013, 23, 79-84. [PubMed]

55. Hauser, G.; Salkic, N.; Vukelic, K.; JajacKnez, A.; Stimac, D. Probiotics for standard triple Helicobacter pylori eradication: A randomized, double-blind, placebo-controlled trial. Medicine (Baltim.) 2015, 94, e685. [CrossRef]

56. Chang, C.W.; Liu, C.Y.; Lee, H.C.; Huang, Y.H.; Li, L.H.; Chiau, J.S.C.; Wang, T.E.; Chu, C.H.; Shih, S.C.; Tsai, T.H.; et al. Lactobacillus casei Variety rhamnosus Probiotic Preventively Attenuates 5-Fluorouracil/Oxaliplatin-Induced Intestinal Injury in a Syngeneic Colorectal Cancer Model. Front. Microbiol. 2018, 9, 983. [CrossRef] [PubMed]

57. Justino, P.F.C.; Melo, L.F.M.; Nogueira, A.F.; Costa, J.V.G.; Silva, L.M.N.; Santos, C.M.; Mendes, W.O.; Costa, M.R.; Franco, A.X.; Lima, A.A.; et al. Treatment with Saccharomyces boulardii reduces the inflammation and dysfunction of the gastrointestinal tract in 5-fluorouracil-induced intestinal mucositis in mice. Br. J. Nutr. 2014, 111, 1611-1621. [CrossRef]

58. Justino, P.F.C.; Melo, L.F.M.; Nogueira, A.F.; Morais, C.M.; Mendes, W.O.; Franco, A.X.; Souza, E.P.; Ribeiro, R.A.; Souza, M.H.; Soares, P.M. Regulatory role of Lactobacillus acidophilus on inflammation and gastric dysmotility in intestinal mucositis induced by 5-fluorouracil in mice. Cancer Chemother. Pharmacol. 2015, 75, 559-567. [CrossRef] 
59. Kato, S.; Hamouda, N.; Kano, Y.; Oikawa, Y.; Tanaka, Y.; Matsumoto, K.; Amagase, K.; Shimakawa, M. Probiotic Bifidobacterium bifidum G9-1 attenuates 5-fluorouracil-induced intestinal mucositis in mice via suppression of dysbiosis-related secondary inflammatory responses. Clin. Exp. Pharmacol. Physiol. 2017, 44, 1017-1025. [CrossRef]

60. Tang, Y.; Wu, Y.; Huang, Z.; Dong, W.; Deng, Y.; Wang, F.; Li, M.; Yuan, J. Administration of probiotic mixture DM\#1 ameliorated 5-fluorouracil-induced intestinal mucositis and dysbiosis in rats. Nutrition 2017, 33, 96-104. [CrossRef]

61. Mi, H.; Dong, Y.; Zhang, B.; Wang, H.; Peter, C.C.K.; Gao, P.; Fu, H.; Gao, Y. Bifidobacterium Infantis Ameliorates Chemotherapy-Induced Intestinal Mucositis Via Regulating T Cell Immunity in Colorectal Cancer Rats. Cell. Physiol. Biochem. 2017, 42, 2330-2341. [CrossRef]

62. Yuan, K.T.; Yu, H.L.; Feng, W.D.; Chong, P.; Yang, T.; Xue, C.L.; Yu, M.; Shi, H.P. Bifidobacterium infantis has a beneficial effect on 5-fluorouracil-induced intestinal mucositis in rats. Benef. Microbes 2015, 6, 113-118. [CrossRef] [PubMed]

63. Bowen, J.M.; Stringer, A.M.; Gibson, R.J.; Yeoh, A.S.J.; Hannam, S.; Keefe, D.M.K. VSL\#3 probiotic treatment reduces chemotherapy-induced diarrhea and weight loss. Cancer Biol. Ther. 2007, 6, 1449-1454. [CrossRef] [PubMed]

64. European Food Safety Authority. Update of the List of QPS-Recommended Biological Agents Intentionally Added to Food or Feed as Notified to EFSA 10: Suitability of Taxonomic Units Notified to EFSA until March 2019. 2019. Available online: https://www.efsa.europa.eu/en/efsajournal/pub/5753 (accessed on 16 August 2019).

65. Vásquez-Morales, A.; Sanz-Valero, J.; Wanden-Berghe, C. Ejercicio excéntrico como recurso físico preventivo en personas mayores de 65 años: Revisión sistemática de la literatura científica. Enferm. Clín. 2013, 23, 48-55. [CrossRef] [PubMed]

(C) 2019 by the authors. Licensee MDPI, Basel, Switzerland. This article is an open access article distributed under the terms and conditions of the Creative Commons Attribution (CC BY) license (http://creativecommons.org/licenses/by/4.0/). 